\begin{tabular}{l|l|c}
\hline \hline Vol. 26(2):187-197 & Ocean and Polar Research & June 2004 \\
\hline \hline
\end{tabular}

\title{
Article
}

\author{
심해저 망간단괴 개발사업의 경제적 타당성 재평가 \\ 남광현 $^{1} \cdot$ 오위영 ${ }^{2 *} \cdot$ 권석재 $^{2}$ \\ 1국회예산정책처 사업평가국 \\ (150-745) 서울특별시 영등포구 여의도동 27-1 \\ 2한국해양연구원 정책조정실 \\ (425-600) 경기도 안산시 안산우체국 사서함 29호
}

\section{An Economic Feasibility Study of Manganese Nodule in Korea Area: Clarion-Clipperton Fracture Zone}

\author{
Kwanghyun Nam ${ }^{1}$, Weeyeong $\mathrm{Oh}^{2 *}$, and Sukjue Kwon ${ }^{2}$ \\ ${ }^{1}$ Program Evaluation Bureau, National Assembly Budget Office \\ Seoul 150-745, Korea \\ ${ }^{2}$ Policy Coordination Department, KORDI \\ Ansan P.O. Box 29, Seoul 425-600, Korea
}

\begin{abstract}
The purpose of this paper is to investigate economic feasibility of manganese nodules in the area obtained by Korea (Clarion-Clipperton Fracture Zone). We assumed that the production scale of manganese nodules were 3.0 MT (million ton(dry)) or $1.5 \mathrm{MT}$, and estimated the capital costs and operating costs by sectors such as exploration, mining, transportation, and metallurgical process. The capital cost and operating cost evaluation reflects the latest technical practices. First, for analyzing economic feasibility, the scenario suggests that the production of 4 metals can be made for 25 years. It is assumed that the discount rate, equity capital, and tax rate are each 8.0\%, 50\%, and 27\%. 3.0 MT of manganese nodule were mined, economic feasibility analyses showed that IRR was 12.8 and pay-back period was 9.2 years, and when 1.5 MT of manganese nodule were mined, economic feasibility analyses showed that IRR was 4.0 and pay-back period was 11.8 years. This study shows that there exists economic feasibility when 3.0 MT of manganese are produced. In addition, we carried out a sensitivity analysis at the change of cobalt price on mining 1.5 MT. The result of sensitivity analysis shows that economic feasibility goes up as increase of cobalt price (50\% up).
\end{abstract}

Key words : 경제적 타당성 분석(Economic feasibility study), 망간단괴(Manganese nodules), 클라리온 클리퍼톤 해역(Clarion-Clipperton Fracture Zone)

\section{1. 서 론}

태평양 클라리온·클리퍼톤 해역(Clarion-Clipperton Fracture Zone)의 우리나라 할당광구에 부존되어 있는 망 간단괴의 경제적 타당성 평가는 1986년, 1992년 및 1997 년에 수행된 바 있다. 그 후 경제적 타당성 평가의 내부요

\footnotetext{
*Corresponding author. E-mail : wyoh@kordi.re.kr
}

인인 심해저 광물자원 개발에 필요한 관련 기술이 급속히 발전하였고, 외부요인인 국제 광물시장에도 상당히 많은 변화가 있었다.

또한 2002년 8월 우리나라는 전체 할당광구의 $20 \%$ 를 포기하여 최종광구로 $74,984.34 \mathrm{~km}^{2}$ 를 확정하였다. 광구 포기 대상지역은 광구면적이 적고, 자원의 부존량이 낮을 뿐만 아니라 대규모 광구와 멀리 떨어진 지역으로 광구개 발의 효율성과 경제성을 고려하여 선정하였다. 
기존의 망간단괴에 관한 경제적 타당성 분석의 대상해 역으로는 주로 하와이 남쪽에서 남동쪽 해역이며, 연간채 광량은 150 만 건톤 또는 300 만 건톤으로 가정하였다.

연간 300 만 건톤의 생산규모는 제련 비용을 최소로 하 기 위해 선택되었다고 생각되며, 연간 150 만 건톤의 생산 규모는 생산되는 금속의 연간 수요량을 고려한 것으로 생 각된다.

최근의 망간단괴를 대상으로 하는 경제적 타당성 분석 은 노르웨이의 기업에 의한 쿡제도의 배타적 경제수역 (EEZ: Exclusive Economic zone)을 대상으로 수행된 것으 로 2001년에 발표되었다(Soredide et al. 2001). 동 연구에 서는 코발트를 중심으로 분석하였으며, 코발트 생산에 따 른 국제가격의 영향을 가능하면 적게 받기 위해서 세계 코발트 연간 수요량의 $10 \%$ 를 생산한다는 가정하에, 제련 공정에 투입하는 망간단괴를 연간 70만 톤으로 설정하였 다. 또한 일본에서도 2002년 하와이 동남부 일본광구에 대한 재평가가 실시되었다(朴洗憲 2003).

따라서 우리나라에서도 2002년 최종 확정된 광구를 대 상으로 최근의 기술개발동향과 광물시장 가격의 변동 상 황을 종합적으로 고려하여 경제적 타당성을 재평가하게 되었다.

본 논문은 서론, 연간수익, 자본비용, 운영비용, 경제적 타당성 평가, 그리고 마지막으로 결론으로 구성되어 있다.

\section{2. 연간 수익}

우리나라는 1994년 8월 2일 대한민국 정부를 대신하여 상공자원부가 유엔으로부터 공해에서의 심해저자원개발 에 관한 선행투자가 자격을 대한민국정부 명의로 인준 받 았으며, 동시에 심해저자원개발을 위한 배타적 탐사권을 행사할 수 있는 할당광구 $150,000 \mathrm{~km}^{2}$ 를 태평양 클라리온 - 클리퍼톤 해역에 등록하였다. 또한 유엔해양법 협약 규 정에 따라 등록한 할당광구의 $50 \%\left(75,000 \mathrm{~km}^{2}\right)$ 를 광구할 당일로부터 8 년 이내에 포기해야하는 의무를 부여받았다.

따라서 1차 광구포기는 1997년 8월 전체 할당광구의 $20 \%$ 인 $30,000 \mathrm{~km}^{2}$ 를, 2 차 광구포기는 1999년 8월 전체 할당광구의 $10 \%$ 를, 3 차 광구포기는 2002년 8월 전체 할 당광구의 $20 \%$ 를 포기하여 최종확정광구 $74,984.34 \mathrm{~km}^{2}$ 를 확보하였다.

최종광구는 6 개 단위광구에 대해 지질학적, 지구물리학 적 및 지구통계학적 방법으로 자원분포조사를 실시하고, 개발가치가 높은 니켈과 동을 대상으로 각 단위광구별 금 속함유분포도를 작성하여 광구개발의 효율성과 경제성이 높은 지역을 대상으로 선정하였으며, 광구면적이 적고 자 원부존량이 낮으며 대규모 광구와 멀리 떨어진 소규모 광 구는 포기하였다(한국해양연구원 심해저자원연구센터, 제
3차 할당광구포기선정).

최종확정광구의 망간단괴 평균 부존밀도는 $6.80 \mathrm{~kg} / \mathrm{km}^{2}$ 이며, 추정 매장량은 509.80 백만 톤(습식 톤 기준)이다. 이 부존량에 건톤 환산 기준인 $70 \%$ 를 적용하면 356.86 백만 건톤으로 연간 300 만 건톤의 망간단괴 채광시 36.3 년간 개발할 수 있는 자원량이며, 연간 150 만 건톤의 망간단괴 채광시 72.6년간 개발할 수 있는 자원량이다.

또한, 망간단괴 함유 4대 금속의 평균 함량은 동 $1.25 \%$, 니켈 $1.37 \%$, 망간, $30.0 \%$ 및 코발트 $0.25 \%$ 로 가 정하였다(Herrouin et al. 1989). 동, 니켈 및 코발트의 제 련효율은 각각 동 $94 \%$, 니켈 $97 \%$, 망간 $93 \%$ 및 코발트 $90 \%$ 로 가정하였고(朴稅憲 2003), 망간의 제련효율은 $93 \%$ 로 가정하였다(John et al. 1983).

따라서 연간 300 만 건톤의 망간단괴 채광시 동, 망간, 니켈 및 코발트의 회수량은 986,100 톤이며, 각 금속의 제 련효율을 적용한 총생산량은 912,117 톤이다. 또한 연간 150 만 건톤의 망간단괴 채광시 동, 망간, 니켈 및 코발트 의 회수량은 493,050 톤이며, 각 금속의 제련효율을 적용 한 총생산량은 456,059 톤이다.

Table 1. Annual production of $\mathrm{Cu}, \mathrm{Ni}, \mathrm{Mn}$ and $\mathrm{Co}$ at the mining of 3 MT (dry) manganese nodules.

\begin{tabular}{lcccc}
\hline Metal & $\begin{array}{c}\text { Mining } \\
\text { (ton) }\end{array}$ & $\begin{array}{c}\text { Metal } \\
\text { content } \\
(\%)\end{array}$ & $\begin{array}{c}\text { Leaching } \\
\text { efficiency } \\
(\%)\end{array}$ & $\begin{array}{c}\text { Annual } \\
\text { production } \\
\text { (ton) }\end{array}$ \\
\hline $\mathrm{Cu}$ & & 1.25 & 94 & 35,250 \\
$\mathrm{Ni}$ & & 1.37 & 97 & 39,867 \\
$\mathrm{Mn}$ & $3,000,000$ & 30.00 & 93 & 837,000 \\
$\mathrm{Co}$ & & 0.25 & 90 & 6,750 \\
\hline
\end{tabular}

Table 2. Annual production of $\mathrm{Cu}, \mathrm{Ni}, \mathrm{Mn}$ and $\mathrm{Co}$ at the mining of $1.5 \mathrm{MT}$ (dry) manganese nodules.

\begin{tabular}{lcccc}
\hline Metal & $\begin{array}{c}\text { Mining } \\
\text { (ton) }\end{array}$ & $\begin{array}{c}\text { Metal } \\
\text { content } \\
(\boldsymbol{\%})\end{array}$ & $\begin{array}{c}\text { Leaching } \\
\text { efficiency } \\
(\boldsymbol{\%})\end{array}$ & $\begin{array}{c}\text { Annual } \\
\text { production } \\
\text { (ton) }\end{array}$ \\
\hline $\mathrm{Cu}$ & & 1.25 & 94 & 17,625 \\
$\mathrm{Ni}$ & \multirow{2}{*}{500,000} & 1.37 & 97 & 19,934 \\
$\mathrm{Mn}$ & & 30.00 & 93 & 418,500 \\
$\mathrm{Co}$ & & 0.25 & 90 & 3,375 \\
\hline
\end{tabular}

기준가격 설정에 있어 본 논문에서는 기존의 국내외 망 간단괴 경제적 타당성 분석에 사용된 가격 설정방법을 비 교 검토한 후 필진들의 합의를 통하여 분석기준 가격을 설정하였다. 가격은 1993년부터 2002년까지 10년간 동, 니켈, 망간 및 코발트의 연평균 가격을 불변가격 기준으로 계산한 값을 적용하였다.

동 가격은 세계금속통계(World Metal Statistics)에서 발 표하는 연평균 가격을 사용하였으며, 니켈 가격은 런던금 
Table 3. Annual average price of $\mathrm{Cu}, \mathrm{Ni}, \mathrm{Mn}$ and $\mathrm{Co}$ (1993-2002).

\begin{tabular}{ccccc}
\hline Year & $\mathbf{C u}$ & $\mathbf{N i}$ & $\mathbf{M n}$ & $\mathbf{C o}$ \\
\hline 1993 & 1,918 & $5,291.0$ & 497 & 30,401 \\
1994 & 2,315 & $6,349.0$ & 492 & 54,365 \\
1995 & 2,932 & $8,223.0$ & 524 & 64,396 \\
1996 & 2,290 & $7,500.1$ & 555 & 56,217 \\
1997 & 2,276 & $6,927.4$ & 473 & 51,455 \\
1998 & 1,653 & $4,629.5$ & 447 & 47,249 \\
1999 & 1,574 & $6,011.2$ & 411 & 37,525 \\
2000 & 1,814 & $8,637.7$ & 505 & 33,418 \\
2001 & 1,578 & $5,948.1$ & 453 & 23,250 \\
2002 & 1,558 & $6,771.8$ & 429 & 15,243 \\
\hline Annual average & 1,991 & $6,629.0$ & 479 & 41,352 \\
price & & & &
\end{tabular}

속시장(London Metal Exchange)에서 발표하는 연평균 가 격을 사용하였다. 망간 가격은 망간합금철인 페로망간의 가격을 기준으로 The Economics of Manganese(Tenth Edition 2003)에 수록된 연평균 가격을 사용하였다. 코발 트 가격은 Metal Week에서 발표하는 연평균 가격을 사용 하였다.

따라서 망간단괴 300 만 건톤 채광시에는 연간 동 70,182천 달러, 니켈 264,278천 달러, 망간 400,923천 달 러, 코발트 279,126 천 달러 등 총 $1,014,510$ 천 달러의 수 익이 발생할 것으로 추정되었다. 또한 망간단괴 150 만 건

Table 4. Annual revenue of $\mathrm{Cu}, \mathrm{Ni}, \mathrm{Mn}$ and $\mathrm{Co}$ at the mining of 3.0 MT (dry) manganese nodules.

\begin{tabular}{lccc}
\hline \multirow{2}{*}{ Metal } & \multicolumn{3}{c}{$\mathbf{3 . 0}$ MT } \\
\cline { 2 - 4 } & $\begin{array}{c}\text { Production } \\
\text { (ton) }\end{array}$ & $\begin{array}{c}\text { Price } \\
\text { (US\$) }\end{array}$ & $\begin{array}{c}\text { Revenue } \\
\text { (US\$) }\end{array}$ \\
\hline $\mathrm{Cu}$ & 35,250 & 1,991 & $70,182,750$ \\
$\mathrm{Ni}$ & 39,867 & 6,629 & 26,4278343 \\
$\mathrm{Mn}$ & 837,000 & 479 & $400,923,000$ \\
$\mathrm{Co}$ & 6,750 & 41,352 & $279,126,000$ \\
\hline Total & - & - & $1,014,510,093$ \\
\hline
\end{tabular}

Table 5. Annual revenue of $\mathrm{Cu}, \mathrm{Ni}, \mathrm{Mn}$ and $\mathrm{Co}$ at the mining of $1.5 \mathrm{MT}$ (dry) manganese nodules.

\begin{tabular}{lccc}
\hline \multirow{2}{*}{ Metal } & \multicolumn{3}{c}{$\mathbf{1 . 5}$ MT } \\
\cline { 2 - 4 } & $\begin{array}{c}\text { Production } \\
\text { (ton) }\end{array}$ & $\begin{array}{c}\text { Price } \\
\text { (US\$) }\end{array}$ & $\begin{array}{c}\text { Revenue } \\
\text { (US\$) }\end{array}$ \\
\hline $\mathrm{Cu}$ & 17,625 & 1,991 & $35,091,375$ \\
$\mathrm{Ni}$ & 19,934 & 6,629 & $132,139,172$ \\
$\mathrm{Mn}$ & 418,500 & 479 & $200,461,500$ \\
$\mathrm{Co}$ & 3,375 & 41,352 & $139,563,000$ \\
\hline Total & - & - & $507,255,047$ \\
\hline
\end{tabular}

톤 채광시에는 연간 동 35,092 천 달러, 니켈 132,139 천 달 러, 망간 200,461천 달러, 코발트 139,563천 달러로 총 507,255 천 달러의 수입이 발생할 것으로 추정되었다. 또한 전체 수익에서 각 금속별 수익이 차지하는 비율은 동 $9.9 \%$, 니켈 $26.0 \%$, 망간 $39.5 \%$, 코발트 $27.5 \%$ 이다.

\section{3. 자본비용}

\section{탐사부문}

탐사선은 망간단괴의 채광이 시작되면 채광당일 작업할 채광선로와 해저면과 관련된 모든 정보를 수집 - 분석하여 채광을 위한 수상시설에 통보해 주어야 한다.

수상시설 1 대당 1 일 건톤 기준으로 5 천톤의 망간단괴 채광이 가능하고, 1 년에 300 일 작업이 가능하다고 가정할 경우 300 만 건톤 채광시 수상시설 2 대가 필요하고, 150 만 건톤 채광시에는 수상시설 1 대가 필요하다. 채광을 위한 수상시설 1대당 탐사선 1대가 지원해야 한다. 따라서 300 만 건톤 채광시에는 2 대의 탐사선, 150 만 건톤 채광시에 는 1 대의 탐사선이 필요하다. 탐사선의 규모와 장비는 현 재 한국해양연구원이 심해 탐사용으로 운용중인 온누리호 ( 1,150 톤급) 정도로 갖춘다고 가정하고, 온누리호의 건조 비를 참고하여 탐사선 1 대당 건조비용을 4백만 달러로 추 정하였다.

\section{채광부문}

망간단괴의 채광시스템은 해상의 채광선, 해저 집광기 및 해저에서 집광된 단괴를 해상까지 끌어올리는 양광장 치로 구성된다. 채광시스템 건조를 위한 자본투자비용은 국내 관련업체와 전문가 자문을 통하여 채광설비의 종류 및 규격, 관련 설비를 설정하고, 국내 조선산업이 건조한 유사한 종류의 선박이나 원유 채굴을 위한 수상시설의 건 조비용 등을 바탕으로 추정하였다.

심해저 망간단괴 채광을 위해 이용될 수 있는 설비로는 이동식 시추 및 저장설비(FPS : Floating Production System, 이하 FPS)가 활용 가능하다. FPS는 유정에서 원 유를 채굴하고, 채굴된 원유에서 물과 가스 등의 불순물을 분리·처리하는 설비를 갖춘 부유체를 총칭하는 것으로서 다양한 크기 및 형태를 가지고 있다. 또한 FPS에는 크게 FPSO(Floating Production, Storage and Offloading System, 이하 FPSO), 반잠수식 플랫폼(Semi-Submersible Platform, 이하 SSP) 및 TLP(Tension Legged Platform, 이하 TLP) 등이 있다. 이러한 설비들 중에서 심해저 사업의 개발성격 을 고려할 때, 심해저 망간단괴 채광을 위해 사용될 수 있 는 설비로는 $\mathrm{FPSO}$ 가 가장 적합하다.

FPSO는 원유의 채굴 및 불순물 제거, 저장, 유조선 (Shuttle Tanker)을 이용한 육상 정제시설로의 운송 등의 
작업이 가능하다. 또한 $\mathrm{FPSO}$ 는 저장과 하역의 통합기능 을 가지면서 이동하는 장점이 있을 뿐만 아니라 건조비용 측면에서도 TLP, SSP 등과 비교하여 저렴하다.

채광방식은 기술 데이터의 축적을 이유로 예항식 집광 기, 양광관 · 플렉시블 호스, 수중펌프에 의한 유체 드레지 방식을 사용하는 것으로 가정하였다. 채광장치의 주행방 식에 있어 예항식은 내구성, 기구, 신뢰성, 보수 - 점검, 동 력, 개발의 난이도 등이 우수하다. 심해 채광 수상시설이 갖추어야 할 기능을 정리하면 다음과 같다.

(1) 채광시스템의 운반 및 견인기능 : 채광작업을 시작 하거나 작업을 종료할 때, 정기적인 보수를 하거나 고장을 수리할 경우, 태풍 등 악천후로 인하여 회항 하여야 할 경우에 채광시스템을 신속하게 철수할 수 있는 견인시스템 또는 운반할 수 있는 시스템

(2) 광석의 처리·저장 및 하역기능 : 단괴는 물과 희석 된 상태로 채광되는데, 희석된 단괴는 저장이나 광 석운반선을 이용한 수송에 적합한 형태가 아니므로 선별기, 분쇄기 등 일정한 과정을 거쳐 농축된 형태 로 생산되며, 이를 광석운반선에 선적할 수 있는 하 역시스템

(3) 부품 및 연료, 보급품의 저장기능 : 대양에서 장기간 의 작업이 필요하다는 점을 고려하여 충분한 연료와 심해저 장비의 부품, 장기간 거주에 필요한 보급품 을 보관할 수 있는 저장시설

(4) 각종 장비의 정비기능 및 시설 : 정기적인 점검과 부 품교체 등을 제외하더라도 일상적인 점검과 예상하 지 못한 고장 등에 대비한 정비시설

(5) 특수항법 및 위치계측시스템 기능 : 정해진 채광선 로를 따라 채광시스템이 작업할 수 있도록 지원하기 위한 위치계측시스템과 항법장치

(6) 헬기 이-착륙장 : 갑작스러운 환자의 발생, 긴급한 보 급품 또는 수리부품의 보급을 위한 헬기 이·착륙장

(7) 동적 위치보정기능 : 해류와 바람으로 인한 채광 수 상시설의 흐름을 방지하고 채광선로를 따라 이동하 기 위한 위치보정시스템
심해채광 수상시설은 채산성 있는 채광속도를 유지할 수 있도록 적절한 작업속도와 양광관과 채광시스템의 운 동보상 및 채광선 선로를 정확히 유지할 수 있는 위치보정 시스템(Dynamic Positioning System)이 요구된다. 또한 심 해저 집광선의 동력과 펌핑력을 적절히 유지하기 위해서 는 매우 큰 용량의 발전설비가 필요하며, 망간단괴나 양광 관을 저장하기 위하여 큰 갑판 수용능력을 확보해야 한다.

심해채광 수상시설의 설비는 엔진 및 발전설비, 거주시 설, 채광시스템의 운반 및 견인장비, 광석의 처리·저장 및 하역시스템, 부품 및 연료와 보급품의 저장시설, 각종 장 비의 정비시설, 특수항법 및 위치계측시스템, 비상시에 대 비한 헬기 이·착륙장 등을 필요로 한다. 또한 심해저 작 업이라는 특수한 환경에서의 조업을 위해 동적 위치보정 시스템(DPS), 채광시스템 등의 장비를 보관하고 수리할 수 있는 장비 및 시설이 필요하다.

이러한 기능과 규모를 갖춘 채광 수상시설은 자본비용 중 가장 큰 부분을 차지하는 것으로서 망간단괴 300 만 건 톤을 심해저에서 채광하기 위해서는 2 척의 채광 수상시설 이 필요하다.

심해저 망간단괴 채광을 위한 수상시설은 연간 300 만 건톤과 150 만 건톤을 채광한다고 가정하고, 연간 조업일 수를 300 일로 가정하면, 1 일 각각 10,000 톤과 5,000 톤을 채광할 수 있는 규모이다.

집광기의 구성은 본체 프레임, 취입장치, 공급장치 및 제어장치 등으로 구성된다. 취입량이 $330 \mathrm{t} / \mathrm{h}$ 인 경우 1 일 한 대의 집광기 가동 시간은 15 시간이다. 집광기의 크기 는 폭 $13.5 \mathrm{~m}$, 길이 $32 \mathrm{~m}$, 높이 $13.5 \mathrm{~m}$ 이며, 대략적인 중 량은 공중중량 80 톤(수중중량 27톤)이다. 동력은 $500 \mathrm{~kW}$, 채광시 속도는 $1.0 \mathrm{~m} / \mathrm{s}$ 로 가정하였다.

본 논문에서는 채광 수상시설이 설계조건과 기능에 따 라 많은 차이가 있으나 $\mathrm{FPSO}$ 선의 경우 대부분 10 만 톤 규모의 저장기능을 보유하고 있다는 점, 이동식 원유 생산 설비를 채광 또는 채굴설비로 재사용이 가능하다는 점 등 을 고려하여 FPSO선을 선정하였다. 따라서 150 만 건톤 채광시의 채광선의 주요항목과 기능은 다음의 표와 같다.

Table 6. Mining ship characteristics of manganese nodules.

\begin{tabular}{ll|lc}
\hline \multicolumn{2}{c|}{ Item } & \multicolumn{2}{c}{ Fuel } \\
\hline Length & $235 \mathrm{~m}$ & Shaft Horsepower & 21,000 Diesel Electric \\
Beam & $43 \mathrm{~m}$ & Sea Speed & 14 Knots \\
Hull Depth & $16.5 \mathrm{~m}$ & 300days Mining & $16,000 \mathrm{HP}$ or 65 LT/day \\
Draft & $12.5 \mathrm{~m}$ & 54days Transferring & $9,200 \mathrm{HP}$ or 37 LT/day \\
Loaded Displacement & 100,000 tons & 20days Transit & 13,000 HP or 52 LT/day \\
Cargo Deadweight & 70,000 tons & 30days Pipe Handling & 6,800 HP or 27 LT/day \\
Mining Equipment & 11,000 tons & & \\
Light Ship Displacement & 19,000 tons & & \\
\hline
\end{tabular}


그 외 채광설비와 관련된 기타 장비의 설치비용은 관련 분야 전문가의 자문과 유사장비의 시장가격 및 선진국의 추정가격 등을 참조하여 아래의 표와 같이 추정하였다.

Table 7. Capital cost inventory at the mining of manganese nodules.

\begin{tabular}{lc}
\hline \multicolumn{1}{c}{$\begin{array}{c}\text { Inventory } \\
\text { (Mining 1.5 MT) }\end{array}$} & $\begin{array}{c}\text { Capital cost } \\
\text { (US\$ million) }\end{array}$ \\
\hline Mining Ship (FPSO) & 94.0 \\
Pumping System & 13.7 \\
Dredge Pipes, Bottom Hoses (1 spare) & 34.9 \\
Collector & 3.4 \\
Set of Onboard Equipment (Handling and & 33.6 \\
Stowage Equipment, Ore Handling) & \\
\hline \multicolumn{2}{c}{ Total } \\
\hline
\end{tabular}

\section{수송부문}

수송부문에 있어 자본비용은 해상수송, 하역시스템, 육 상수송 및 지원시설에 투자된다. 해상수송에 있어서 필요 한 수송선의 수는 광석운반선의 규모, 광구와 항구간의 거 리, 연간 채광량, 광석운반선의 속도 등에 의해 결정된다. 대상 광구로부터 우리나라까지의 거리는 약 5,800해리이 고, 수송선의 규모는 70,000톤, 수송선의 속도를 15 노트로 가정하며 16.1 일이 걸린다. 하역기간을 고려한 왕복 수송 기간은 35일로 연간 9회 수송할 수 있다. 따라서 수송선 1 척의 연간 수송량은 습식 톤 기준으로 63만 톤이다. 이것 을 건톤 기준으로 환산하면 44.1만 톤이다. 따라서 300만 톤을 수송하기 위해서는 7척, 150 만 톤을 수송하기 위해서 는 4척이 필요하다. 본 논문에서는 기존의 연구를 참고하 여 70,000 톤급 운반선의 가격은 40 백만 달러로 추정하였다.

광석운반선은 선체, 슬러지 운반장비, 연료 및 용수, 보 급품 저장 운반장비, 채광선과 연결시스템, 폐기물처리 장 비 등으로 구성된다. 뿐만 아니라 광석운반선에는 격벽이 있는 특수화물 창이 있기 때문에 습식단괴로부터 흘러내 린 물이 선저에 차는 위험을 감소시키면서 습식단괴를 운 반할 수 있도록 펌핑시스템을 설치하여 운송초기에 선저 에 고인 물을 배출시키는 기능을 갖추어야 한다. 다만 화 물창에 펌핑시스템을 갖추는 것은 선가에 포함되는 것으 로 가정하면, 이러한 기능을 갖춘 광석운반선의 자본비용

Table 8. Capital cost of marine transportation system.

\begin{tabular}{lc}
\hline \multicolumn{1}{c}{ Item (70,000 t) } & Capital cost (US\$ million) \\
\hline Transport Vessel & 40.0 \\
Loading System & 2.0 \\
Storage equipment & 0.5 \\
Port-to-Plant Transport & 1.0 \\
\hline \multicolumn{1}{c}{ Total } & 43.5 \\
\hline
\end{tabular}

은 다음과 같다.

하역시설은 망간단괴 수송을 위한 광석운반선이 기존 항만에 입항하고, 기존항만에 망간단괴 하역을 위한 전용 터미널을 건설하는 것으로 가정하였다. 하역터미널 건설 비용은 TAMU 2차 모형에서 추정한 비용을 적용하여 제 련소의 위치와 상관없이 연간 300만 건톤 생산시 38.6백 만 달러, 연간 150 만 건톤 생산시에는 300 만 건톤의 자본 투자비용의 $70 \%$ 인 27 백만 달러로 추정하였다.

육상수송의 자본투자비용은 TAMU 2차 모형을 적용하 여 제련소의 위치와 상관없이 연간 300 만 톤 생산시에는 23.5 백만 달러, 연간 150 만 톤 생산시에는 16.6 백만 달러 로 추정하였다.

망간단괴 채광을 위한 수상시설이 효율적으로 운영되기 위해서는 채광지역 근처에 채광인력이 장기간 체류해야 한다. 또한 장기간 체류에 대비한 소비재, 부품, 연료 등 물자보급 및 작업 교대근무자에 대한 수송 등을 담당할 보급시설과 보급선이 필요하다. 프랑스의 GEMONOD 연 구에서는 채광 작업장에서 가장 가까운 선진국에 위치한 미국 캘리포니아에 후방 보급기지를 설치하도록 되어 있 다(다금속 단괴 개발방법론 평가 및 연구 1988). 이 기지 에서는 개발에 참여하는 직원 및 가족이 숙박하며, 설비 일부분의 유지 · 관리, 교체부품 및 채광작업장이 운영되 는데 필요한 소비재 및 연료 등을 구입하고 보관한다. 150 만 건톤 기준으로 보급선은 20 노트 이상의 속력을 유지할 수 있는 선박으로 관련전문가의 자문을 통하여 17.8 백만 달러로 추정하고, 보급시설은 2.5 백만 달러로 추정하였 다. 300 만 건톤의 경우 보급선은 20 백만 달러, 보급시설은 3백만 달러로 추정하였다.

\section{제련부문}

제련시스템 선정에 있어서는 망간단괴 제련을 위해 제 안되어 있는 처리법 중 다른 침출법과 시험결과 비용측면 에서 비교우위가 있는 염산침출법을 이용하여 그 처리시 설의 비용을 추정하였다. 제련설비비용은 제련분야 기술 개발을 주도하고 있는 한국지질자원연구원의 제련팀에서 추정하였다. 실제 비용추정은 연간 망간단괴 100 만 톤 처 리규모의 플랜트에 대하여 수행하였고, 300만 건톤과 150 만 건톤의 경우 비용계산을 위하여 장치산업의 생산규모 증가에 따른 다음과 같은 비용추정식을 사용하여 추정하 였다.

$$
C_{1}=C_{0} \times R^{n} \quad(0<n \leq 1)
$$

여기서, $C_{1}$ 은 확대된 생산규모의 비용, $C_{0}$ 는 원래의 생산 규모의 비용, $R$ 은 생산규모 확대율, $n$ 은 투자승수, 투자비 용에 대해서는 0.6 , 운영비용에 0.88 을 적용하였다. 따라 
서 제련소 공정설치비와 부대시설비용을 모두 합친 투자 비용의 합계는 100 만 톤 처리규모에서 185 백만 달러로 추 정되었다. 이를 앞에서 제시하였던 비용추정식에 대입하 면 처리규모 150 만 건톤, 300 백만 건톤일 때의 투자비용 으로 각각 250 백만 달러, 380 백만 달러가 도출된다.

제련 후에 발생하는 제련잔사를 처리하는 방법이 환경 문제와 관련하여 중요하게 부각되고 있다. TAMU 모형에 서는 연간 300 만 톤의 망간단괴를 생산하는 경우에 제련 잔사 폐기처리를 위하여 제련소로부터 100 마일 이내에 총 1,700 에이커(약 208 만평)의 폐기물 처리장을 건설하는 것 을 가정하고 있다. 부지매입 비용은 미국의 낮은 토지가격 을 반영하여 불과 11.1백만 달러를 계상하고 있다. 우리나 라의 경우 200 만평 정도의 부지를 제련잔사의 폐기처리를 위해 조성하려면 높은 토지비용과 입지난으로 인해 막대 한 투자비용이 소요된다. 제련잔사의 처리 또는 재이용 문 제는 단순한 처리비용의 문제가 아니라 환경문제와 관련 있기 때문에 잔사의 처리 또는 재활용을 위해서는 성분분 석 및 환경영향평가 등에 대한 실질적인 연구가 필요하다. 지난 1995년에 이루어진 망간단괴 제련잔사 처리에 관 한 연구결과(정문영 1995)를 살펴보면, 망간단괴 제련잔 사의 독성이 미국 환경청(EPA) 기준을 초과하지 않는 것 으로 분석하고 있다. 용융 후 황산침출공정의 잔사는 입도 가 큰 비반응성의 유기물질로서 안정성이 뛰어나 적당히 파쇄하면 도로기반 충전제로 사용할 수 있다는 것이다. 이 처럼 잔사의 활용이 가능하다면, 폐기물 처리비용을 거의 지출하지 않아도 된다. 본 논문에서는 이러한 연구결과를 바탕으로 제련잔사를 재활용한다고 가정하고 폐기물 처리 비용은 고려하지 않았다. 잔사의 취급 및 반출에 소요되는 비용은 재활용되는 잔사의 판매비용에 의해 상쇄된다고 가정하였다.

연간 망간단괴 300 만 건톤을 제련하기 위한 제련소 건 설을 위해서는 넓은 부지가 필요하다. 수송되어온 망간단 괴와 생산시설 및 부품 등을 저장 및 보관할 수 있는 공간 과 관리부서, 복지시설 등을 건축하기 위한 부지의 확보가 필요하다. 1982년 미국 매사추세츠 공과대학에서 수행한 연구(MIT 모형)에서는 이러한 공간수요를 감안하여 제련 소 건설을 위해 약 500에이커(약 61만평)의 부지가 필요 하다고 가정하였다. 제련소 부지 매입비용은 미국의 낮은 토지가격을 반영하여 2백만 달러를 가정하고 있다. 우리 나라의 경우에는 토지가격이 상대적으로 높기 때문에 제 련소 부지매입비용은 이보다 훨씬 크게 나타날 것이다.

제련소 부지는 감가 혹은 감모가 발생하지 않는 고정자 산으로 심해저 광업이 종료된 이후에 매도할 경우에도 자 산손실이 별로 발생하지 않는다. 즉, 우리나라의 토지가격 은 상당기간이 경과하여도 구입비용 이상의 가치를 유지 하는 경우가 대부분이기 때문에, 부지구입에 대한 투자비
용은 초기 자본지출에만 영향을 줄 뿐 사업의 수익성에는 영향을 주지 않는다. 따라서 국내에서 추진되는 사업의 경 제성 분석에서는 토지구입 비용을 경제성 분석에서 제외 하거나, 또는 토지의 잔존가치를 평가해주는 경우가 대부 분이다. 그러나 토지구입 비용은 토지가격의 상승으로 초 기투자 비용보다 높게 나타나는 경우 대부분이기 때문에 비용을 제외하는 경우와 거의 동일한 결과를 나타낸다.

본 논문에서는 초기에 제련소 부지구입이 초기투자비용 에는 포함되지만, 수익률 변화에는 영향을 미치지 않는 것 으로 가정한다. 즉 토지가격이 실질적인 사회적 할인율과 동일한 수준으로 상승하여 심해저 사업이 완료된 후에 다 시 매각되는 것으로 간주한다. 이와 같이 가정한 제련소 부지 매입비용은 저장공간과 지원시설 공간의 활용효율을 최대한 높여서 MIT 모형에서 상정한 제련소 부지 면적의 절반에 약간 못 미치는 30 만평으로 가정하였다.

포항종합제철은 건평 약 270 만평, 조강생산 1,200 만톤 이며, 광양제철은 건평 약 450 만평, 조강생산 1,600 만톤, 고려아연(주)은 건평 약 28 만평, 아연괴 생산능력 30 만톤 이다. 이들 3 곳의 평당 생산능력을 보면 포항종합제철은 약 4.4톤, 광양제철은 약 3,6톤으로 높은 편이나, 고려아연 (주)는 0.93 톤에 불과하다. 그러나 제련소 건설을 위한 부 지면적은 공정과 생산하는 제품에 따라 크게 달라진다. 즉, 단순히 단괴만을 생산할 경우 부지면적은 크게 줄어들 지만, 최근의 추세와 같이 산업에서 필요로 하는 여러 가 지 복합제품을 생산할 경우에는 부지면적이 크게 증가하 는 것이 일반적이다. 고려아연(주)의 경우는 광산물 제련 에 의해 아연괴, 카드늄괴, 전기동, 산화코발트, 황산 $(10 \%$ 이상), 산화카드늄, 염화아연, 황하아연 및 기타 부산물 등 을 복합적으로 생산하는 종합공정이다. 연괴, 은괴, 금괴, 주석괴, 비스머스괴, 앤티모니괴, 산화앤티모니괴 및 기타 비철금속을 제조 판매하며, 에너지 효율을 높이기 위한 열 병합발전소를 건설하여 온산공단업체에 판매하는 종합공 정을 운영하는 등 생산능력에 비해 넓은 부지면적을 보유 하고 있는 것으로 조사되었다.

광양제철의 사례를 참고하여 망간단괴 300 만 건톤을 제 련하기 위해서는 약 24 만평 정도가 필요하고, 기타 시설 6 만평 정도를 포함한다면 총 30 만평이 필요하다. 우리나라 의 공단분양가를 감안하여 평당 45 만원에 제련소 부지를 매입한다고 가정하면 총 112 백만 달러가 필요하다. 또한

Table 9. Capital cost of metallurgical process.

\begin{tabular}{|c|c|c|}
\hline Inventory & $\begin{array}{c}\text { 3.0 MT } \\
\text { (US\$ million) }\end{array}$ & $\begin{array}{c}1.5 \mathrm{MT} \\
\text { (US\$ million) }\end{array}$ \\
\hline Plant and Equipment & 380 & 250 \\
\hline Land & 112 & 74 \\
\hline Total & 492 & 324 \\
\hline
\end{tabular}


망간단괴 150 만 건톤을 제련하기 위해서는 제련소 면적으 로 16 만평이 필요하고, 기타 시설 4 만평을 포함하면 총 20 만평이 필요하다. 따라서 150 만 건톤을 제련하기 위해 제련소 부지를 매입비로 총 74 백만 달러가 필요하다.

생산설비에 대한 자본투자가 진행되는 동안 시설의 시 험운전 및 관리에 비용이 소요된다. 이러한 비용은 수입이 발생하지 않는 상태에서 지출됨으로서 자본투자비용의 성 격을 갖는다. 본 논문에서는 시설 및 설비분야 투자의 $10 \%$ 가 시험운전 및 관리에 소요된다고 가정하였다. 또한 1 차년도에 전체 시험운전 및 관리비용의 $10 \%, 2$ 차년도에 전체 시험운전 및 관리비용의 $10 \%, 3$ 차년도에 전체 시험 운전 및 관리비용의 $20 \%, 4$ 차년도에는 전체 시험운전 및 관리비용의 $30 \%, 5$ 차년도에는 전체 시험운전 및 관리비 용의 $30 \%$ 가 투자된다고 가정하였다. 또한 연도별 시설 및 설비의 자본투자비용은 1 차년도에는 전체 시설 및 설비 자본투자비용의 $10 \%, 2$ 차년도에는 전체 시설 및 설비 자 본투자비용의 $20 \%, 3$ 차년도에는 전체 시설 및 설비 자본 투자비용의 $30 \%, 4$ 차년도에는 전체 시설 및 설비 자본투 자비용의 $30 \%, 5$ 차년도에는 전체 시설 및 설비 자본투자 비용의 $10 \%$ 가 투자된다고 가정하였다.

이상에서는 각 부문별 시설과 시험운전 분야를 중심으 로 살펴본 자본비용을 종합하면 다음과 같다.

Table 10. Total capital cost to product 4 metals.

\begin{tabular}{lcc}
\hline \multicolumn{1}{c}{ Cost } & $\begin{array}{c}\mathbf{3 . 0} \text { MT } \\
\text { (US\$ million) }\end{array}$ & $\begin{array}{c}\text { 1.5 MT } \\
\text { (US\$ million) }\end{array}$ \\
\hline Exploration & 4.0 & 2.0 \\
Mining System & 374.5 & 214.0 \\
Transportation & 452.6 & 278.1 \\
Metallurgical Process & 380.0 & 250.0 \\
Working Capital & 121.1 & 74.4 \\
\hline \multicolumn{1}{c}{ Total } & $1,332.2$ & 818.5 \\
\hline
\end{tabular}

\section{4. 연간 운영비용}

\section{탐사 및 연구개발 부문}

탐사부문의 연간 운영비용은 현재 한국해양연구원이 보 유-운영중인 온누리호의 항해비용을 바탕으로 추정하였 다. 현재 온누리호의 연간운영비는 승무원 및 육상지원인 력 인건비, 연료비, 휴항비용, 선박 일반장비 수리비, 첨단 장비 유지 - 보수비, 보험료, 휴항비용 등으로 고려할 때 2001년 기준으로 약 281만달러 정도가 소요되고 있는데, 여기에서 육상지원인력 인건비 등을 제외할 경우 245 만달 러가 된다. 따라서 탐사선 운영을 위해서는 약 2.5 백만 달 러가 소요될 것으로 추정된다. 이러한 연간 운영비용을 고 려할 때 연간 300 만 건톤 채광의 경우에는 탐사선 2척 운
영에 투입되는 연간 운영비용은 5.0백만 달러, 연간 150 만 건톤 채광의 경우에는 탐사선 1 척에 2.5 백만 달러가 지출 되는 것으로 추정하였다.

300 만 건톤 채광시 연구개발비용은 상업생산 기간 중 제련효율 향상과 해양환경 보전연구를 중심으로 수행되며 연간 4백만 달러가 소요되는 것으로 추정하였으며, 150 만 건톤 채광시 연구개발비용은 300 만 건톤 채광시의 $70 \%$ 인 2.8 백만 달러가 소요되는 것으로 추정하였다.

\section{채광부문}

채광부문의 운영비는 유지보수비, 인건비, 연료비, 보험 료, 그리고 휴항비로 구성된다. 유지보수비용은 기존자료 를 이용하여 장비 및 보급품 운영은 해당항목 자본지출의 $5 \%$, 망간단괴 펌핑시스템, 드렛지 파이프라인, 집광시스 템은 각 $50 \%$, 광석처리는 $5 \%$, 채광 수상시설은 자본지출 의 $2 \%$ 가 유지보수비용으로 소요될 것으로 예상하여 총 19.2백만 달러로 추정하였다.

인건비는 채광작업 인력과 수상시설(또는 채광선) 인력 을 추정한 후, 1 인당 평균임금을 곱하여 추정하였다. 채광 을 위한 수상시설의 운용을 위해 필요한 인원은 채광을 위한 수상시설 운영인원 및 채광작업에 필요한 인력 등 각 50 인씩 총 100 명이 필요할 것으로 예상된다. 선원과 작업인원은 2 개조로 편성하여 수개월씩 교대로 작업에 참 여하게 되므로 수상시설에 승선하여 실제 작업에 참여하 는 인원은 50 명이 된다. 일인당 평균임금은 고급 기술인 력의 수요와 작업의 난이성, 위험성 등을 가정하여 71,000 달러 수준으로 추정하였다. 따라서 채광 수상시설의 1 인 당 연간 인건비 총액은 7.1백만 달러로 추정하였다.

연료비는 연료가격과 설비동력을 감안하여 추정하였 다. 연료소비는 시간당 165 그램/마력, 윤활유소비는 시간 당 1 그램/마력, 디젤유 가격은 158 달러/톤, 윤활유 가격은 950달러/톤으로 가정하여 수상시설당 연료비는 연간 4.7 백만 달러 정도로 추정하였다.

연간보험료는 채광부문 장비 총가격의 $1.5 \%$ 에 해당하 는 금액과 온누리호 보험료를 참고하여 선원 1 인당 1,000 달러씩 지출하는 것으로 가정하고 채광선당 2.9 백만 달러 로 추정하였다.

휴항비용은 수상시설이 채광작업을 하지 않고 정박해 있는 동안의 운영비로서 유지보수비, 연간인건비, 보험료 의 일정비율로 산정하여 수상시설당 0.3 백만 달러로 추정 하였다.

\section{수송부문}

해상수송부문의 연간운영비는 인건비, 유지보수비, 보 험료, 연료비, 항만사용료, 그리고 휴항비용 등으로 구성 된다. 기존의 연구에서는 선원 1 인당 연간급료를 약 
67,000 달러로 계산하고, 수송선 1척당 인건비를 약 2.0 백 만 달러로 추정하였다.

광석운반선의 유지보수비용은 엔진 최대 가동비율과 중 량톤의 함수로 추정되며, 슬러리 시스템의 유지보수비용 은 슬러리 시스템 기본비용의 $10 \%$ 로 추정된다. 따라서 수 송선의 연간 유지보수비용은 0.7 백만 달러로 추정되었다.

보험료는 수송선의 중량톤과 자본지출의 함수이다. 이 렇게 산출된 연간보험료는 약 0.8 백만 달러이다. 수송선 1 척당 연료비용을 추정하기 위하여 먼저 디젤엔진 연료 및 윤활유 비용을 다음과 같이 산출하였다.

$$
\text { 일당연료비용 }=s f c \times M C R \times c b c \times \frac{24}{1,000,000 \times 1.2}
$$

위 식에서 $s f c$ 는 일당 특정연료(윤활유) 소모량(그램/마 력-시)이며, $M C R$ 은 엔진최대가동효율, $c b c$ 는 톤당 가격 이다. 주 엔진의 연료소모량과 윤활유 소모량은 각각 155 그램/마력 · 시, 0.93그램/마력 · 시이고, 보조엔진의 연료 소모량 및 윤활유소모량은 각각 165 그램/마력·시, 1그램 /마력-시로 가정하였다. 또한 보조엔진에 사용되는 동력 은 주 엔진 최대가동률의 $4 \%$ 로 가정하되, 해상에서 선적 이 이루어지는 동안에는 주 엔진 최대가동률의 $40 \%$ 로 가 동될 것으로 예상하였다. 이렇게 하여 산출된 연간 연료비 는 3.0 백만 달러이다.

항만비용은 수집 가능한 데이터의 선형회귀분석에 의해 연간 약 0.2 백만 달러로 산정하였다. 또한 휴항비용은 연 간 0.2 백만 달러로 추정하였다.

본 논문에서는 해상수송부문의 연간운영비는 현재 국내 제련소에서 운영중인 실적선 자료를 중심으로 추정하였 다. 수송선의 중량톤별 선원 수는 노선, 수송광물, 선박의 자동화 정도에 따라 많은 차이가 있기 때문에 일률적으로 적용하기는 매우 힘든 실정이며, 신조선의 경우 자동화 기 술이 급격하게 발전됨에 따라 인건비를 줄이기 위하여 선 원 수가 감소하는 추세를 보이고 있다.

인건비는 국내 제련소에서 운영하는 실적선을 중심으로 선원 1 인당 연간급여를 약 65,000 달러로 계산할 때, 42 명 기준의 광석운반선 1 척당 인건비는 약 2.7 백만 달러로 추 정된다.

유지보수비는 신조선의 경우 유지보수비가 낮은 편이 나, 선령이 10 년을 넘는 선박의 경우에는 3 4년 단위로 정기적인 보수를 하고 있는데, 수리 및 보수비용이 2백만 달러 정도가 소요된다. 이를 평균하면 약 0.6백만 달러가 된다. 보험료(선원보험료 포함) 및 연료비는 실적선의 자 료를 활용하여 1.0 백만 달러와 4.1 백만 달러로 추정하였으 며, 항만비용 및 휴항비용은 각각 0.1 백만 달러로 추정하 였다.

하역터미널의 연간 운영비는 TAMU 모형을 준용한 '97
년의 연구결과를 활용하여 연간 300 만톤 채광의 경우 4.5 백만 달러, 연간 150 만톤을 생산하는 경우에는 3.7 백만 달 러로 추정하였다. 육상수송의 운영비도 기존의 철로를 일 부 확장하여 사용한다는 전제 아래 TAMU 모형을 준용하 여 연간 300 만톤 생산시 6.2 백만 달러, 연간 150 만톤 생산 시 3.7 백만 달러로 추정하였다.

물자보급 및 인력 교대를 위한 보급선은 유지보수비, 인건비, 보험료, 연료비, 휴항비 등을 관련자문가 및 관련 업체의 자문에 의하여 추정하였다. 그 결과 연간 300 만 건 톤 채광시 1.2 백만 달러, 150 만 건톤 채광시는 0.8 백만 달 러가 소요된다.

\section{제련부문}

제련부문 운영비는 제련분야의 기술개발을 주도하고 있 는 한국지질자원연구원의 제련팀에서 추정한 자료를 이용 하였다. 제련부문의 운영비는 전력요금, 염산, 암모니아 등 화학제품비, 소모품비 및 기타 비용을 포함하였다. 본 논문에서 비용을 추정하기 위한 제련방식은 염산추출법을 이용하는 것으로 가정하고 평가하였으나, 현재 검토중인 용련-습식침출법을 적용한 세부적인 비용추정은 이루어지 지 못하고 있다. 연구개발을 통하여 최종적인 공정 선택이 이루어진 후에 보다 세부적인 운영비용 분석이 추진되어 야 할 것이다.

특히 우리나라의 산업용 전력요금은 일반적으로 선진국 보다는 비싼 수준이며, 전력사용량, 종류, 계절 부하시간 대에 따라 달라지나, 우리나라의 현재 산업용 전력요금을 평균하여 대략 $\mathrm{kWh}$ 당 50 원을 적용하였다. 그 결과 300 만 톤 채광시 제련부문에 있어 연간 운영비용은 311 백만 달 러, 150 만 건톤 채광시에는 170 백만 달러로 추정되었다.

\section{경영관리}

경영관리부문의 운영비는 ' 97 년의 연구결과를 준용하여 300 만 톤 생산의 경우 6.4 백만 달러, 150 만 톤 생산시 연 간 4.5 백만 달러의 운영비가 지출되는 것으로 추정하였다.

\section{연간 총 운영비용}

150 만톤 채광시 총 운영비용에서 탐사 및 연구개발 부 문이 차지하는 비율은 $2.1 \%$, 채광부문은 $13.3 \%$, 수송부문 은 $16.6 \%$, 제련부문은 $66.3 \%$, 그리고 해상지원 및 경영관 리부문은 $1.7 \%$ 를 차지한다. 300 만 톤 채광시에는 150 만 톤 채광시 보다 전체 운영비용이 1.8 배 증가하며, 각 부문 이 차지하는 비율측면에서 볼 때 탐사 및 연구개발 부문 은 $2.1 \%$ 에서 $1.9 \%$ 로 감소하고, 채광부문은 $13.3 \%$ 에서 $14.6 \%$ 로 증가하고, 수송부문은 $16.6 . \%$ 에서 $15.4 \%$ 로 감소 하고, 제련부문은 $63.3 \%$ 에서 $66.3 \%$ 로 증가하고 해상지원 및 경영관리 부문은 $1.7 \%$ 에서 $1.4 \%$ 로 감소한다. 즉, 생산 
Table 11. Total operating cost to product 4 metals.

\begin{tabular}{lcc}
\hline \multicolumn{1}{c}{ Sectors } & $\begin{array}{c}\text { 3.0 MT } \\
\text { (US\$million) }\end{array}$ & $\begin{array}{c}\text { 1.50 MT } \\
\text { (US\$million) }\end{array}$ \\
\hline Exploration & 9.0 & 5.3 \\
Mining & 68.4 & 34.2 \\
Transportation & 72.1 & 42.4 \\
Metallurgical Process & 311.0 & 170.0 \\
Management & 6.4 & 4.4 \\
\hline \multicolumn{1}{c}{ Total } & 466.9 & 256.3 \\
\hline
\end{tabular}

규모가 증가함에 따라 탐사 및 연구개발부문, 수송부문, 해상지원 및 경영관리분야가 차지하는 비율은 감소하고, 채광부문과 제련부문에서 차지하는 비율은 증가하지만 그 폭은 그다지 크지 않은 것으로 분석되었다.

\section{5. 경제적 타당성 평가}

경제적 타당성 평가는 자기자본에 대한 세후 수익률을 기준으로 분석하였다. 여기서 사용된 분석기법은 재무분 석의 일반적 분석방법인 현금흐름할인법을 사용하였으며, 수익과 비용항목은 2000년 기준 불변 미국달러를 기준으 로 추정하였다.

경제적 타당성 평가의 중요한 요인이 되는 망간단괴 4 대 광물의 가격은 1993년부터 2002년까지의 연평균 국제 가격을 기준으로 하였다. 생산량은 연간 망간단괴 300 만 건톤을 채광하여 유용금속을 생산하는 경우와 연간 망간 단괴 150 만 건톤을 채광하여 유용금속을 생산하는 경우로 나누어 분석하였다. 그러나 연간 300 만 건톤을 채광하여 유용금속을 생산하는 경우, 방대한 생산규모에 따른 초기 투자에 대한 부담과 니켈 및 코발트의 대량생산에 따른 금속가격 하락에 대한 위험성 및 자금조달의 어려움 등의 단점이 있지만, 대규모 생산설비를 통해 광석 단위당 비용 이 적게 들어간다는 장점이 있다. 150 만 건톤 채광시에는 300 만 건톤 채광시 보다 초기투자에 대한 부담, 니켈과 코 발트의 대량생산에 따른 금속가격 하락에 대한 위험성, 자 금조달의 어려움 등의 영향을 적게 받는다는 장점과 150 만 건톤을 채광해서 유용금속을 공급할 경우 국내에서 충 분히 소비될 수 있다는 장점이 있으나, 광석 단위당 비용 은 300만 건톤보다 비효율적이라는 단점이 있다.

자본투자비용과 운영비용의 추정방법은 국내 연관사업 의 유사프로젝트 사례, 기술수준, 비용구조 등을 반영하였 으며, 국내 관련기관 전문가의 의견과 직접 시장조사를 통 하여 추정하였다. 또한 기술적인 변수는 가능하면 국내 기 술을 근거로 추정하였으나, 기술비용에 대한 국내자료가 부재인 경우는 2002년 일본의 망간단괴 경제적 타당성 분 석결과, 1988 년 프랑스 GEMONOD의 망간단괴 경제적
타당성 분석결과 및 2001년 노르웨이에서 수행한 쿡제도 의 망간단괴 경제적 타당성 분석결과 등을 인용하였다.

투자수익을 판단하는 방법으로는 자본회수 기간과 내부 수익률법을 사용하여 경제적 타당성을 분석하였다. 자본 회수 기간은 세금공제 후 이익과 예비금 합계의 연차누적 액이 자산투자액에 도달하는 연수를 의미한다.

여기서 수익은 다음과 같이 정의한다.

수익 $\left(B_{t}\right)=$ 감가상각비 + 세금공제 후 수익 - 차입금 변제

내부수익률은 최초 년도의 비용과 그 다음해부터 할인 된 순수익의 합계가 일치하도록 하여 내부수익률 IRR를 도출하였다. 이 내부수익률이 할인율보다 크면 그 사업은 경제적 타당성이 있다고 평가하며 다음과 같이 나타낸다.

$$
\sum_{t=0}^{n} \frac{\left(B_{t}-C_{t}\right)}{(1+I R R)^{t}}=0 \quad(t=0,1,2, \ldots, n)
$$

경제적 타당성 평가에 있어서 미래의 서로 다른 기간에 발생하는 비용과 수입을 객관적으로 비교하려면 투자자금 의 기회비용을 반영할 수 있는 할인율의 결정이 중요하 다. 왜냐하면 할인율이 높아질수록 초기투자 비용의 현재 가치는 증대하는 반면 상당기간이 경과한 후에 발생하는 편익의 현재가치는 적어지기 때문이다.

본 논문에서는 다음과 같은 조건을 가정하고 망간단괴 의 경제적 타당성 평가를 수행하였다.

첫째, 본 논문에서 사용한 할인율은 2002년 하와이 동 남동 지역의 일본광구를 대상으로 실시한 망간단괴 개발 의 경제적 타당성 평가와 2001년 쿡제도의 배타적 경제수 역을 대상으로 노르웨이가 실시한 망간단괴 개발사업 경 제적 타당성 평가에서 사용한 $8 \%$ 를 적용하였다.

둘째, 자기자본비율은 $50 \%$ 로 가정하였다. 또한 차입금 리는 $8 \%$ 로 가정하였으며, 차입금은 12 년 이내에 변제하 는 것으로 가정하였다.

셋째, 망간단괴 유용금속을 생산하는 데까지 우선 시설 및 설비자본투자에 5년이 걸린다고 가정하였으며, 생산 첫해는 생산가능능력의 $50 \%$ 를 생산하고, 그 다음해 부터 는 생산가능능력의 $100 \%$ 를 생산한다고 가정하였다.

넷째, 국제해저기구에 납부하는 로열티는 현재는 그 효 력이 정지되어 있으나, 유엔해양법협약 제 3 부속서 제 13 조 에 따라 상업생산 최초연도부터 10 년간은 총매출액의 $5 \%$, 그 이후로는 $12 \%$ 를 납부해야 한다고 가정하였다.

다섯째, 법인세율은 2002년 1월 1일 이후 적용되는 법 인세 과세체계에 따라 $27 \%$ 를 적용하였다.

여섯째, 감가상각비는 설비투자에 의해 고정화된 자산 을 1 년이라도 빨리 감가상각에 의해 유동화 하는 것이 경 제적으로 유리하기 때문에 감각상각 속도가 빠른 정률 감 가상각법을 사용하였다. 
일곱째, 각 운전비용(조업자재, 에너지비용, 침출잔사처 리비용 및 인건비 등)은 분석기간 동안 단가의 변동이 없 는 것으로 가정하였다.

여덟째, 개발시스템은 건설에서 경제적 조업까지 총 30 년을 가정하였으며, 선박과 플랜트 건설에 5년, 1 년 간 테 스트 가동 후 7 년째부터 24년간 사용된다고 가정하였다. 이러한 가정하에서 도출된 자본회수 기간과 내부수익률은 다음과 같다.

Table 12. Results of the feasibility study for development manganese nodules

\begin{tabular}{ccc}
\hline Production scale & Payback periods & IRR $(\boldsymbol{\%})$ \\
\hline 3.0 MT & 9.2 years & 12.8 \\
$1.5 \mathrm{MT}$ & 11.8 years & 4.0 \\
\hline
\end{tabular}

300 만 건톤 채광시에는 자본회수 기간이 9.2년이며, 내 부수익률은 $12.8 \%$ 로 경제적 타당성이 있는 것으로 분석 되었으며, 150 만 건톤 채광시에는 자본회수 기간이 $11.8 \%$ 이며, 내부수익률은 $4.0 \%$ 로 경제적 타당성이 다소 미흡한 것으로 분석되었다.

또한 본 논문에서는 코발트 가격이 $10 \%$ 에서 $50 \%$ 까지 상승할 경우를 가정하여 경제적 타당성 평가 지표에 얼마 나 영향을 주는 지를 민감도 분석을 통하여 살펴보았다. 민감도 분석결과 300 만 건톤을 채광하는 경우에는 코발트 의 가격이 $10 \%$ 상승함에 따라 내부수익률이 $0.7 \%$ 정도 상승하며, 150 만 건톤을 채광하는 경우에는 내부수익률이 약 $0.9 \%$ 정도 내부수익률이 개선되는 것으로 분석되었 다. 광물가격의 변동에 따라 내부수익률에 대한 민감도가 매우 높고, 그 정도는 300 만 건톤 채광시보다 150 만 건톤 채광시가 더 높은 것으로 분석되고 있다.

Table 13. Results of the sensitivity analysis at the changing of cobalt price

\begin{tabular}{lcc}
\hline $\begin{array}{c}\text { Sensitivity factors } \\
\text { (Cobalt Price) }\end{array}$ & $\begin{array}{c}\text { IRR(\%) of the } \\
\text { mining 3.0 MT }\end{array}$ & $\begin{array}{c}\text { IRR(\%) of the } \\
\text { mining 1.5 MT }\end{array}$ \\
\hline Increasing by 10\% up & 13.9 & 5.0 \\
Increasing by 20\% up & 14.7 & 6.0 \\
Increasing by 30\% up & 15.4 & 6.9 \\
Increasing by 40\% up & 16.1 & 7.8 \\
Increasing by 50\% up & 16.8 & 8.7 \\
\hline
\end{tabular}

\section{6. 결 론}

본 논문에서는 태평양 클라리온 - 클리퍼톤 해역의 우리 나라 할당광구를 대상으로 최근의 기술수준과 경제현황을 근거로 분석하였다. 300 만 건톤 채광시에는 자본회수 기
간이 9.2년이며, 내부수익률은 $12.8 \%$ 로 경제적 타당성이 있는 것으로 분석되었으며, 150 만 건톤 채광시에는 자본 회수 기간이 $11.8 \%$ 이며, 내부수익률은 $4.0 \%$ 로 경제적 타 당성이 다소 미흡한 것으로 분석되었다.

같은 광구를 대상으로 수행하였던 기존의 경제적 타당 성 평가 결과와 비교하면 기술개발의 효과가 반영되어 자 본비용과 운영비용 측면에서는 비용이 절감된 것으로 분 석되었으며, 수익 측면에서는 최근의 낮은 광물가격을 반 영되어 적은 수익이 발생할 것으로 분석되었다. 종합적으 로는 기존의 경제적 타당성 분석결과와 비교하여 경제적 타당성을 나타내는 지표가 낮았다.

또한 민감도 분석에서 150 만 건톤 채광시 경제적 타당 성을 얻기 위해서는 코발트 가격이 기준가격보다 $50 \%$ 이 상 대폭 상승할 경우에 경제적 타당성이 있는 것으로 분 석되었다.

\section{사 사}

본 연구는 해양수산부의 지원으로 수행된 '심해저 자원 개발 제도분석, 연구의 일환으로 수행되었다.

\section{참고문헌}

朴洗憲. 2003. 深海鑛物資源の經濟性分析. 博士學位論文, 東 京大學

오위영, 남광현. 2003. 심해저 망간단괴의 초기투자 비용 비 교·분석 연구. 선박해양기술, 36. 85-95.

정문영. 1995. 망간단괴 제련잔사의 특성과 활용방안. 제 2회 심해저 망간단괴 처리기술 워크숍.

조동성. 2003. 국제경영. 경문사.

한국해양연구원 심해저자원연구센터. 2002. 제3차 할당광구 포기선정.

해양수산부. 1997. '97 심해저 광물자원탐사 보고서 III 심해 저 자원개발 법제도 및 경제성 분야.

해양수산부. 2004. 2003년 심해저 광물자원탐사 보고서 III 심해저 자원개발 제도분석.

해양수산부, 한국해양연구원, 한국지질자원연구원. 2003. 심 해저 광물자원 개발 로드맵.

홍승용. 1988. 심해저 망간단괴광업의 경제성 평가에 관한 연구. 경희대학교. 박사학위논문. $267 \mathrm{p}$.

홍승용, 강정극. 1993. 심해저 자원개발론. 서울프레스. $316 \mathrm{p}$. 황기형. 1995. 우리나라 심해저 망간단괴 개발사업의 경제성 에 관한 연구. Ocean Res., 17(2), 157-175.

황기형, 조규남. 1997. 우리나라 심해저 광물자원 개발사업의 경제성 평가 연구. 해양정책, 12, 41-74.

Glasby, G.P. 2000. Economic geology: Lessons from deep-see minings. Science, 289, 551-553.

Herrouin, G. et al. 1989. A manganese nodule industrial 
venture would be profitable: summary of a 4 year study in France. presented at the 21st Annual Offshore Technology Conference in Huston, Texas.

International Ocean Institute. 2003. The feasibility of commercial production of deep-sea mineral resources including analysis of international trends relating to mineral resources. submitted to KORDI.

John, E.F. et al. 1983. The economic viability of a fourmetal pioneer deep ocean mining venture. College Station, Texas.

Magnuson, G.W.H. 2002. The economic value of ocean resources the United States, for the use of the committee on commerce pursuant to S. Res. 222. National
Ocean Policy Study. Books for Business New YorkHong Kong.

Søreide, F., T. Lund, and J.M. Markussen. 2001. Deep ocean mining reconsidered a study of the manganese nodule deposits in Cook Island. p. 88-93. In: The Proceeding of the Fourth ISOPE-OMS. Szczecin, Poland, September 23-27.

United States Geological Survey. 2003. Mineral commodity summaries 1989-2003. http://minerals.usgs.gov/minerals/ pubs/mcs/ 